\title{
PRIORITIZATION OF STRATEGIES FOR BREZOVICA SKI RESORT DEVELOPMENT USING SWOT-AHP METHODOLOGY
}

\author{
Bojan Stojčetović ${ }^{1}$ \\ Sanja Marković ${ }^{2}$ \\ Živče Šarkoćević ${ }^{3}$
}

DOI: https://doi.org/10.31410/tmt.2019.459

\begin{abstract}
Purpose of this chapter is to define relevant strategies for the development of ski resort Brezovica. To this end, the hybrid SWOT-AHP methodology was applied to get insight at the current state. The SWOT analysis included a total of 24 factors. Based on the current situation, appropriate development strategies have been defined. A total of 6 strategies have been defined. However, conventional SWOT analysis does not allow the evaluation and ranking of these strategies. That is why the AHP methodology is introduced. According to the results, the WT1 strategy (development all-year-round tourist offer availability) is top ranked. Also, sensitivity analysis of SWOT groups and factors of highest importance (S1, W2, O1, T4, and T6) was performed. According to the results of the sensitivity analysis, all changes in the rank of the strategies are the result of changes of more than $10 \%$ relative to the initial values of SWOT groups and factors, so it can be concluded that the proposed model is stable and the results obtained are relevant.
\end{abstract}

Keywords: SWOT, AHP, Brezovica.

\section{INTRODUCTION}

$\mathrm{T}^{\mathrm{o}}$ ourism represents an important part in many economies. For example, tourism generates $10 \%$ of GDP and represents 9\% of total employment in the European Union (EU). Further, international arrivals to EU destinations are expected to increase by an average of 9 million a year through $2030(+1.9 \%$ a year) (European Union tourism trends, 2018). Also, in less developed regions, the local community may derive significant economic-social benefits from tourism (Zhenhua, 2003). According (Mansury and Hara, 2007) tourism may be primarily viewed as a branch of industry which simultaneously promotes economic growth and equality, by including the use of local inputs - local commodities, as well as the involvement of the local manpower. Unfortunately, Serbian tourism potentials have not been sufficiently valorized, because tourism has never been an important subject of the Republic of Serbia development policy.

In particular, winter tourism can represent one of the main sources of income for local population across several industries, including accommodation, food services, transportation, arts and entertainment, and retail trade (Ballotta et al., 2020). Until 1999, winter tourism was a significant source of income for the population of the Štrpce municipality, thanks to the Brezovica ski resort located on the territory of the municipality. One of the main problem ski resorts faced is current climate evolution. For that reason, ski resorts experience increasing difficulty to provide services for the whole of the winter season. If winter sports resorts are particularly vulnerable to climate change (Agrawala, 2007; Simpson et al., 2008), this is even more dramatic for those that are located at lower altitudes.

\footnotetext{
1 High Technical School of Professional Education Zvecan, Nušićeva 6, Zvečan

2 High Technical School of Professional Education Zvecan, Nušićeva 6, Zvečan

$3 \quad$ Faculty of Technical Sciences, Knjaza Milosa 7, Kosovska Mitrovica
} 
In addition to climate problems, Brezovica ski resort has faced many other challenges since 1999. In order to analyse current status and to define strategies for development SWOT analysis is applied. It is one of the most efficient and commonly used tools in the preliminary decision-making phases and as a precursor to strategic planning (Srivastava et al., 2005). It is used in the case of strategy planning, in order to identify the potential and priorities for the accomplishment of the development strategy (Buta, 2007). However, one of the main disadvantages of conventional SWOT analysis is the inability to evaluate the results (SWOT groups, factors and strategies). This drawback can be eliminated using the appropriate multicriteria decision making (MCDM) methods (Stojčetović et al., 2018, p. 863). To that end (Kurttila et al., 2000) introduced a hybrid SWOT-Analytical Hierarchy Process (AHP) model which has been one of the commonly used approaches. A potential advantage of using AHP within a SWOT analysis is possibility for the quantitative assessment of SWOT factors and the inclusion of decision makers' preferences in planning (Kurttila et al, 2000).

The SWOT-AHP method has been successfully applied in many areas: environment (Kurtila et al., 2000; Masozera et al., 2006), sport (Lee and Walsh, 2011), telecommunication (Mehmood et al., 2014), energetics (Stojčetović et al., 2016; Stojcetovic et al., 2018). Also, SWOT-AHP has also been applied in the tourism sector (Kajanus et al., 2004; Fabac and Zver, 2011) as well to determine and evaluate strategies: (Kangas et al, 2003) evaluate the management strategies of a forestland estate; (Yuksek i Alkin, 2006) determine the business strategy in textile firm; (Nikolić et al., 2015) to determine and prioritize strategy in tourist sector.

\section{METHODOLOGY}

In order to define and prioritize strategies, the model presented in Figure 1 was applied. The proposed model consists of 4 steps and is based on the hybrid SWOT-AHP methodology. The goal of this paper is to define and prioritize strategies for tourism development in Brezovica.

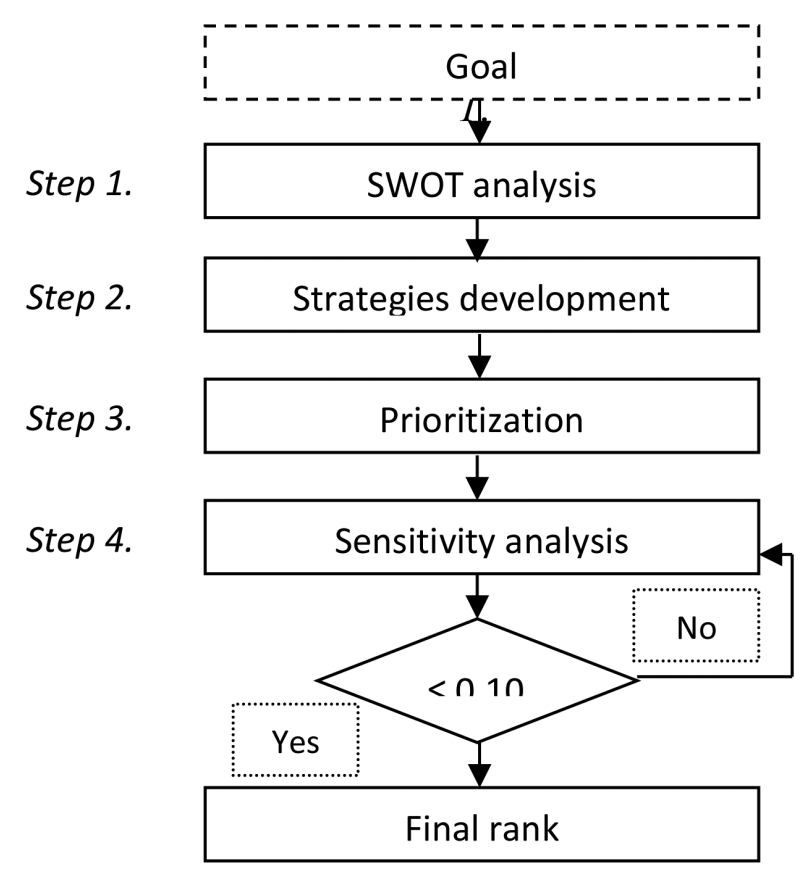

Figure 1. Proposed model

The basics of the methods applied in the proposed model are presented in the text that follows. 


\subsection{SWOT analysis}

The description of internal strengths and weaknesses as well as external opportunities and threats is the core of SWOT analysis (Houben et al., 1999). SWOT analysis is most often presented in the format shown in Table 1.

Table 1. SWOT analysis

\begin{tabular}{|c|c|c|}
\cline { 2 - 3 } \multicolumn{1}{c|}{} & Internal factors & External factors \\
\hline \multirow{2}{*}{ Desirable factors } & Strengths & Opportunities \\
& $(1 \ldots \ldots \mathrm{n})$ & $(1 \ldots . \mathrm{n})$ \\
\hline \multirow{2}{*}{ Undesirable factors } & Weaknesses & Threats \\
& $(1 \ldots \ldots \mathrm{n})$ & $(1 \ldots . \mathrm{n})$ \\
\hline
\end{tabular}

The success of any organization or project depends on the internal and external environment. SWOT analysis provides insight into both environments in a way that makes the relevant decision possible. The result of a SWOT analysis is a list of statements or factors that describe current or future trends from the internal and external environment, which are generally general and brief (Eslamipoor and Sepehriar, 2014). However, when is used properly, SWOT analysis can provide a good basis for strategy formulation (Kajanus et al., 2004).

According to Stojčetović et al. (2016) SWOT analysis is easy to conduct and does not require specific knowledge for its implementation and understanding. Despite the advantages, the use of conventional SWOT analysis does not allow determining the significance of each SWOT factor (Shinno et al., 2006). Therefore, the result of a SWOT analysis may be a superficial and imprecise list or an incomplete qualitative examination of internal and external factors (Kurttila et al., 2000).

\subsection{Analytical hierarchy process}

The AHP method was developed by Saaty (1980). Applying the AHP methodology can decompose a complex problem into a multi-level structure of goals, criteria and alternatives (Sharma et al., 2008). AHP structure is shown on Figure 2.

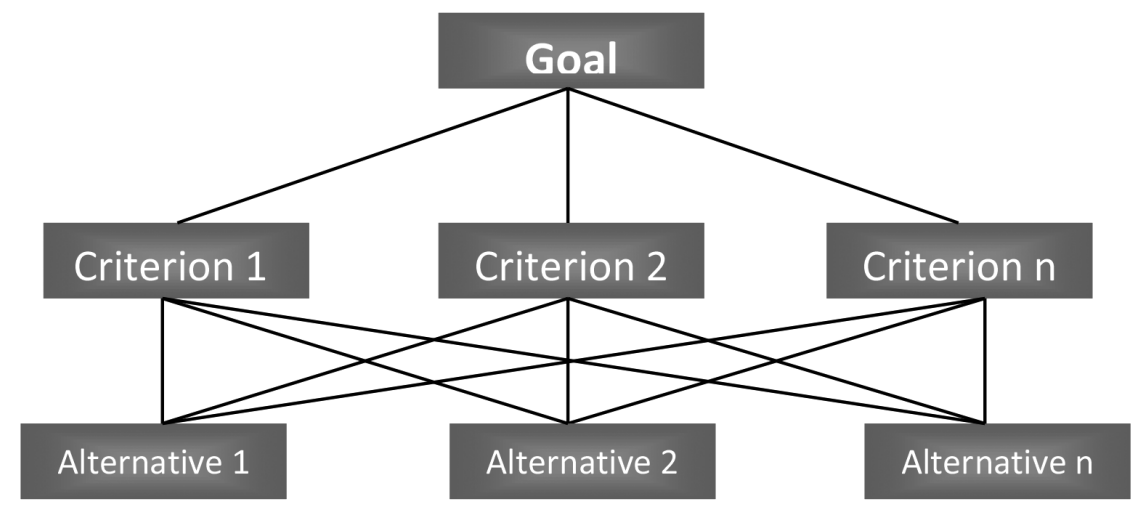

Figure 2. AHP structure

In order to solve the problem of hierarchical structure, AHP procedure is defined as follows (Shahabi et al., 2014):

1. Step 1: The hierarchical structure is defined so that the goal is at the top of the hierarchy while the criteria and strategies are positioned in descending order; 
2. Step 2: At each level, a pairwise comparison matrix is obtained. A scale (Table 2) ranging from 1 (equal importance) to 9 (absolute importance) is used to identify the priorities of each criterion (alternative) over the other criteria (alternatives);

3. Step 3: All pairwise matrices are synthesized to calculate the relative and global weights of each criterion, sub-criterion and alternative.

Defining a hierarchy is a very important step of the AHP, although it is often not given adequate importance. The hierarchy needs to be defined in the right way, otherwise this initial step may lead to a decision that is not relevant.

To perform pairwise comparisons of all relevant criteria/alternatives, Saaty proposes to form an $n \times n$ pairwise comparison matrix A:

$$
\mathrm{A}=\left(\begin{array}{cccc}
a_{11} & a_{12} & \cdots & a_{11} \\
a_{21} & a_{22} & \cdots & a_{2 n} \\
\cdots & \cdots & \cdots & \cdots \\
a_{n 1} & a_{n 2} & \cdots & a_{n n}
\end{array}\right)
$$

whereby $a_{i j}$ values are obtained using the 9-point scale defined by Saaty (1980).

Table 2. Saaty scale

\begin{tabular}{|l|l|l|}
\hline Intensity & Definition & Explanation \\
\hline 1. $\mathbf{1}$ & 2. Equal significance & 3. The two activities contribute equally to the goal. \\
\hline 4. $\mathbf{3}$ & 5. Moderate significance & $\begin{array}{l}\text { 6. Experience and evaluation slightly favor one } \\
\text { activity over another }\end{array}$ \\
\hline 7. $\mathbf{5}$ & 8. Strong significance & $\begin{array}{l}\text { 9. Experience and assessment strongly favor one } \\
\text { activity over another }\end{array}$ \\
\hline 10. $\mathbf{7}$ & $\begin{array}{l}\text { 11. Very strong or demonstrated } \\
\text { significance }\end{array}$ & $\begin{array}{l}\text { 12. One activity j is strongly favored over another; its } \\
\text { dominance has been demonstrated in practice. }\end{array}$ \\
\hline 13. $\mathbf{9}$ & 14. Absolute significance & $\begin{array}{l}\text { 15. Evidence favoring one activity over another is the } \\
\text { highest possible level of validation. }\end{array}$ \\
\hline 16. $\mathbf{2 , 4 , 6 , 8}$ & 17. Inter-results & $\begin{array}{l}\text { 18. They are used to make a compromise between the } \\
\text { priorities outlined above. }\end{array}$ \\
\hline
\end{tabular}

Matrix A is a positive reciprocal matrix in which $a_{i j}$ represents the preference ratio of the alternative $i$ with respect to the alternative $j$. The $a_{i j}$ value is the reciprocal of the $a_{j i}$ value. That is,

$$
a_{i j}=1 / a_{j i}
$$

If the pairwise comparisons are consistent then $a_{i j}$ elements of matrix A satisfy the equation:

$$
a_{i j} * a_{j k}=a_{i k}, \text { for each } \mathrm{i}, \mathrm{j}, \mathrm{k} \text {. }
$$

Weighting factor of criteria/alternatives can be marked with $w_{i}$.

If matrix A is consistent $a_{i j}$ can be represented as $a_{i j}=W_{i} / W_{j}$, for each $i \mathrm{i} j$ 
Therefore, if $\mathrm{A}$ is consistent then: $\mathrm{A} * \mathrm{~W}=\left(\begin{array}{cccc}\frac{\mathcal{W}_{1}}{\mathcal{W}_{1}} & \frac{\mathcal{W}_{1}}{\mathcal{W}_{2}} & \ldots & \frac{\mathcal{W}_{1}}{\mathcal{W}_{n}} \\ \frac{\mathcal{W}_{2}}{\mathcal{W}_{1}} & \frac{\mathcal{W}_{2}}{\mathcal{W}_{2}} & \ldots & \frac{\mathcal{W}_{2}}{\mathcal{W}_{n}} \\ \ldots & \ldots & \ldots & \ldots \\ \frac{\mathcal{W}_{n}}{\mathcal{W}_{1}} & \frac{\mathcal{W}_{n}}{\mathcal{W}_{2}} & \ldots & \frac{\mathcal{W}_{n}}{\mathcal{W}_{n}}\end{array}\right) *\left(\begin{array}{c}\mathcal{W}_{1} \\ \mathcal{W}_{2} \\ \ldots \\ \mathcal{W}_{n}\end{array}\right)=\mathrm{n} *\left(\begin{array}{c}\mathcal{W}_{1} \\ \mathcal{W}_{2} \\ \ldots \\ \mathcal{W}_{n}\end{array}\right)$

By normalizing the matrix $\mathrm{A}=\left[a_{i j}\right]_{\mathrm{nxn}}$ the weight factor is calculated as follows:

$$
a_{i j}^{*}=\frac{a_{i j}}{\sum_{i=1}^{n} a_{i j}} \text { for each } \mathrm{j}=1,2, \ldots, \mathrm{n} \text {. }
$$

Then:

$$
w_{i}=\frac{\sum_{i=1}^{n} a_{i j}}{n} \text { for each } \mathrm{j}=1,2, \ldots, \mathrm{n} .
$$

To determine the level of consistency, a consistency index (CI) is proposed and can be calculated according to the following equation:

$$
C I=\frac{\lambda_{\max }-n}{n-1}
$$

Where $\lambda_{\max }$ is a parameter for validation in AHP. The closer the value of $\lambda_{\max }$ is to $n$, the more consistent the estimate is.

The consistency ratio can be calculated using the following formula:

$$
C R=\frac{C I}{R I}
$$

wherein RI (Random index) is a random consistency index whose values for $(\mathrm{n} \leq 10)$ are given in Table 3.

Table 3. Average RI values

\begin{tabular}{|c|c|c|c|c|c|c|c|c|c|c|}
\hline $\mathbf{n}$ & $\mathbf{1}$ & $\mathbf{2}$ & $\mathbf{3}$ & $\mathbf{4}$ & $\mathbf{5}$ & $\mathbf{6}$ & $\mathbf{7}$ & $\mathbf{8}$ & $\mathbf{9}$ & $\mathbf{1 0}$ \\
\hline $\mathbf{R I}$ & 0 & 0 & 0.58 & 0.90 & 1.12 & 1.24 & 1.32 & 1.41 & 1.45 & 1.49 \\
\hline
\end{tabular}

When $\mathrm{CR}<0.10$, the matrix can be evaluated as acceptable, otherwise, the matrix should be modified to reach an acceptable size (Ren and Sovacool, 2015). Factor homogeneity within each group, fewer factors in the group, and a better understanding of decision problems can improve the consistency index (Saaty, 1993). 


\subsection{Research area}

Brezovica is a ski resort on the south of $\operatorname{Kosovo}^{4 *}$ (Figure 3). From 1999. to 2008., the territory of Kosovo* was provisionally administered by the international community and NATO, and in 2008. the provisional administration of Kosovo* declared independence. Kosovo ${ }^{*}$ has no direct access to the sea and possesses a mostly hilly-mountain terrain. However, it has a favourable climate and multiple natural, cultural, and historical resources.

The Ministry of Trade and Industry has signed tourism development agreements with Albania (2006), Macedonia (2013). Also, Kosovo* and Macedonia have established a joint committee for cross-border economic cooperation, where tourism is given special attention. Capacity utilization in Kosovo ${ }^{*}$ regions in percentage for the period 2013-2017 is shown in Table 4. However, capacity utilization is insufficient.

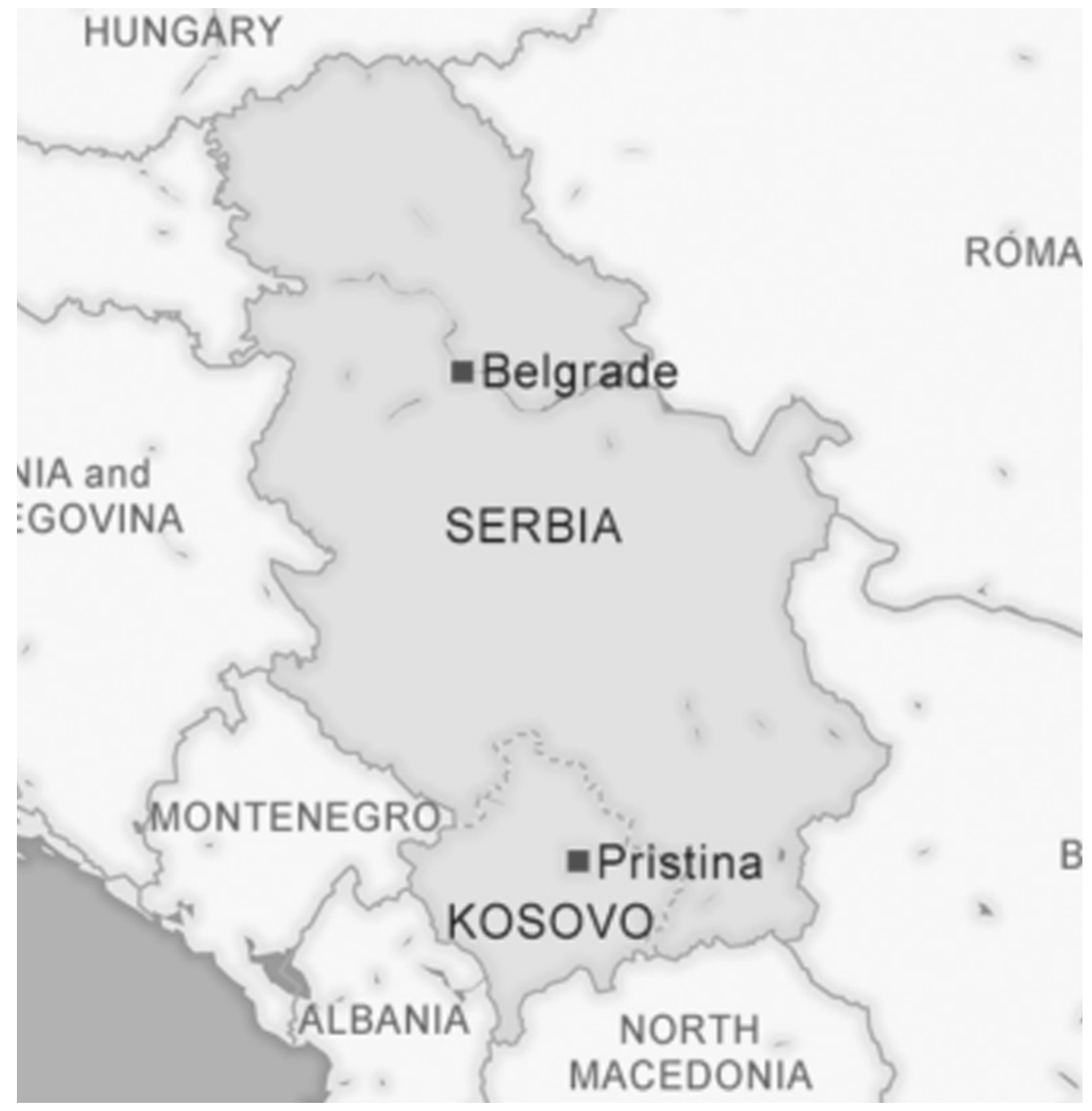

Figure 3. Kosovo* geographical position 4,* "This designation is without prejudice to the status of Kosovo in accordance with UNSCR 1244 and the
ICJ Opinion on the Kosovo declaration of independence." 
Table 4. Capacity utilization in Kosovo* regions in percentage for the period 2013-2017

\begin{tabular}{|c|c|c|c|c|c|c|c|}
\hline $\begin{array}{c}\text { Region/ } \\
\text { year }\end{array}$ & Đakovica & Gnjilane & Mitrovica & Peć & Prizren & Priština & Uroševac \\
\hline 2013 & 1.64 & 3.48 & 2.99 & 4.57 & 4.57 & 18.43 & 12.58 \\
\hline $\mathbf{2 0 1 4}$ & 3.78 & 1.73 & 2.30 & 4.29 & 4.29 & 17.21 & 2.10 \\
\hline $\mathbf{2 0 1 5}$ & 5.44 & 4.51 & 6.53 & 11.67 & 11.67 & 25.05 & 4.93 \\
\hline $\mathbf{2 0 1 6}$ & 5.39 & 2.43 & 4.00 & 5.36 & 5.36 & 17.52 & 4.38 \\
\hline $\mathbf{2 0 1 7}$ & 3.50 & 5.12 & 9.22 & 13.42 & 13.42 & 15.52 & 5.00 \\
\hline
\end{tabular}

Source: State statistical office in Kosovo, 2017.

Brezovica ski resort is situated on northwest side of Shar mountain at altitude of 900 to 2.500 meters. In the highest parts of mountain snow stays up to 280 days which make this resort ideal environment for winter sports and recreational tourism. Ski resort Brezovica represents a system of 5 ropeway ( 2 is off) and 5 ski lifts (1 is on), interconnected with $16 \mathrm{~km}$ of ski paths of the average length of 3.000 meters (Figure 4).

Numerous successful competitions are held before 1999. at national and international level. From 1999. due to political and legal issues, ski resort working with minimal capacity. Also, the infrastructure is damaged and collapsed significantly. Brezovica ski resort has repeatedly been subject to takeover/privatization by the Kosovo Privatization Agency. However, privatization has not been realized.

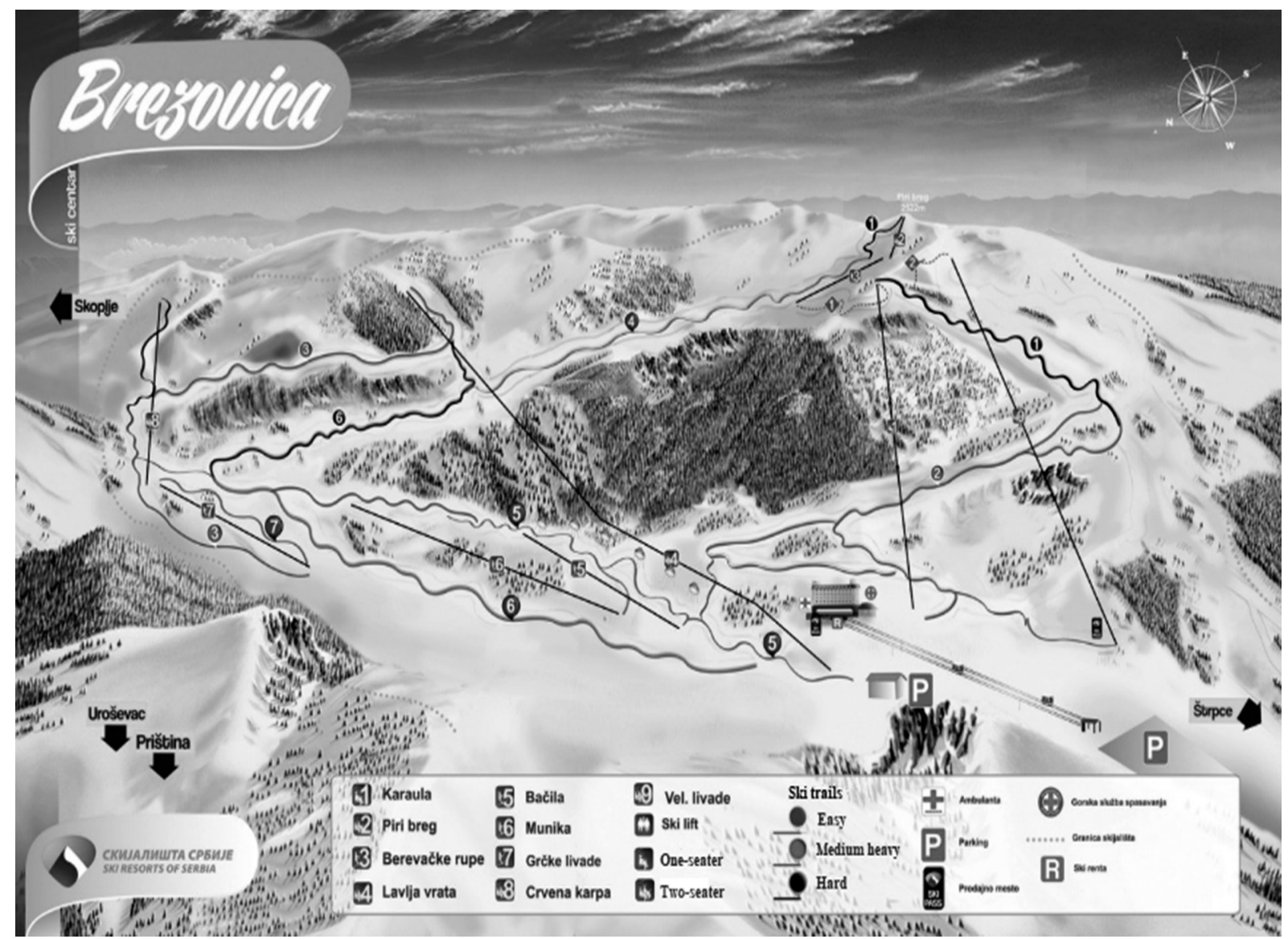

Figure 4. Brezovica ski trails 


\section{RESULTS AND DISCUSION}

In the Step 1. a SWOT analysis of the Brezovica ski resort was carried out. For the purposes of SWOT analysis, existing documents were reviewed as well as relevant literature. Also, a survey of the management of the Brezovica ski resort was conducted. Based on the above, an initial SWOT matrix was formed containing 40 factors. Then, all the identified SWOT factors were evaluated using scores from 0-insignificant to 1-essential with incremental increments of 0.1. Only factors rated $\geq 0.8$ are included in the final SWOT matrix (Table 5) and will be used to define and evaluate strategies.

SWOT analysis enables the generation of 4 categories of strategies: SO (optimal use of strengths for taking advantage of opportunities), ST (use of strengths for minimizing threats), WO (using of opportunities for minimizing weaknesses), WT (minimizing threats by considering weaknesses) (Alptekin, 2013; Terry and Westbrook, 1997). In Step 2., based on the SWOT analysis, appropriate strategies have been defined to improve the current situation in the tourism sector and to help its future development. A total of six strategies have been defined (Table 4). The strategies defined are briefly described in the text that follows.

Exploitation of unique natural, ecological and cultural features in order to differentiate from competitors $\left(\mathbf{S O}_{\mathbf{1}}\right)$ - In Brezovica, i.e. Šar mountains, there are 1,800 plant species and 147 species of daily butterflies, 45 species of amphibians and reptiles, about 200 species of birds and 32 species of mammals, making it one of the fauna-richest areas of Europe (Damnjanović, 2009). Also, near Brezovica there are two small mountain lakes and 27 lakes on the Shar mountain territory.

Creating a joint offer with North Macedonia with the support of $\mathbf{E U}$ funds $\left(\mathrm{SO}_{2}\right)$ - A grant from the European Union Funds is one of the ways to provide the necessary funds to realize project ideas. These funds, among others, promote and encourage cross-border cooperation between neighboring countries. In this regard, suitable projects could be defined to cover regions extending into the Shar mountain range in the border zone of countries. In this way, in addition to providing the necessary financial resources, the tourist offer of the region can be enriched.

Defining new tourist contents and improving the quality in accordance with the needs of tourists and available potentials $\left(\mathbf{S T}_{1}\right)$ - Currently, only skiing is available to the tourists in the Brezovica ski resort. There are no other tourist contents. This has a negative impact on increasing the number of tourists and extending of stay of the existing ones. Therefore, it is necessary to provide conditions for new tourist offer (such as backcountry skiing, cross country skiing, snow-shoeing, snow playing, sledging, sightseeing, paragliding etc.). In this way, tourist satisfaction and higher income can be achieved.

Defining a Tourism Development Strategy $\left(\mathbf{W O}_{1}\right)$ - Currently there is no strategic document for tourism development. The consequence is a lack of clearly defined directions and development goals.

Development of human resources through cooperation with educational institutions $\left(\mathrm{WO}_{2}\right)$ - One of the problems in the tourism sector is the lack of quality human resources. The currently available human resources in Brezovica ski resort are over 50 years old. This means that in the next decade, almost all employees will be eligible for retirement. On the other hand, there are not enough expertly educated young people who can fill the future needs in the tourism sector. 
Therefore, close cooperation with educational institutions is required as human resources development is a long-term process.

Development all-year-round tourist contents availability $\left(\mathbf{W T}_{1}\right)$ - Currently, to the tourists is only offered content during the winter months, mainly from January to March. The contents offered are for winter sports only. The rest of the year ( 9 months) is completely unused. In order to attract more visitors and increase revenue, it is necessary to define appropriate tourist contents that will be available throughout the whole year. Mountaineering, hiking, climbing, horse-riding, mountain biking and other activities (alpine coaster, fishing etc.) can be some of the added activities. Also, possibilities of congress tourism development should be considered.

Table 5. SWOT analysis and strategies

\begin{tabular}{|c|c|c|}
\hline & \multirow[b]{2}{*}{ STRENGTHS } & \multirow[b]{3}{*}{ 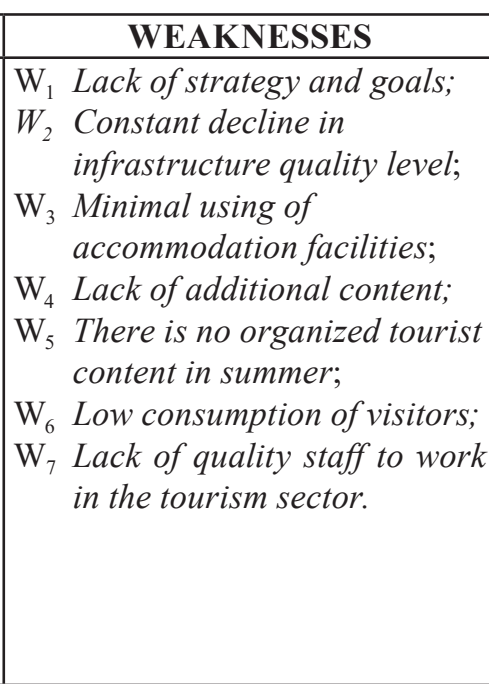 } \\
\hline & & \\
\hline & 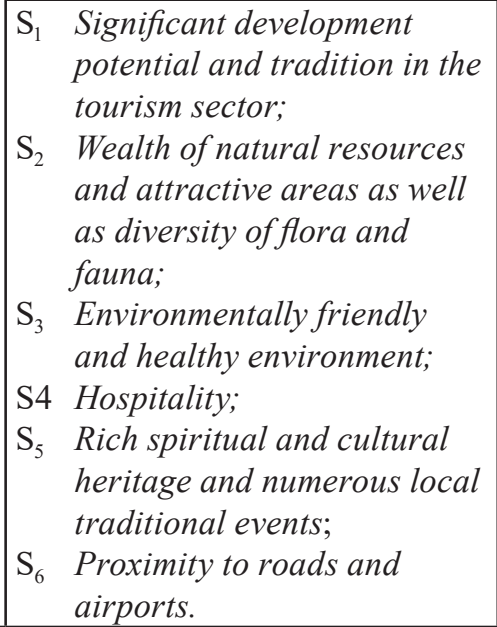 & \\
\hline OPPORTUNITIES & \multirow[b]{2}{*}{\begin{tabular}{|c|} 
SO strategy \\
SO \\
Exploitation of unique \\
natural, ecological and \\
cultural features in order \\
to differentiate from \\
competitors. \\
SO $_{2}$ Creating a joint tourist offer \\
with N. Macedonia with the \\
support of EU funds
\end{tabular}} & \multirow[b]{2}{*}{ 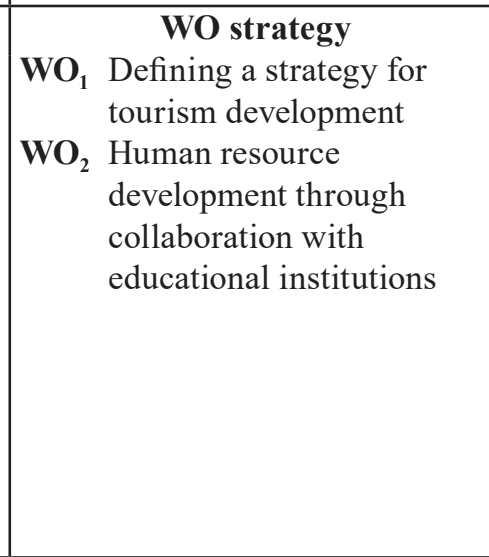 } \\
\hline $\begin{array}{ll}\mathrm{O}_{1} & \begin{array}{l}\text { Extending the tourist season } \\
\text { throughout the year by adding } \\
\text { new content and improving }\end{array} \\
& \text { infrastructure; } \\
\mathrm{O}_{2} & \text { Rural tourism development; } \\
\mathrm{O}_{3} & \text { Donor financial and expert support; } \\
\mathrm{O}_{4} & \text { The stabilization of the } \\
& \text { macroeconomic and political } \\
& \text { environment; } \\
\mathrm{O}_{5} & \text { The possibility of cooperation with } \\
& \text { North Macedonia through EU funds } \\
& \text { for tourism. }\end{array}$ & & \\
\hline TREATHS & \multirow[b]{2}{*}{$\begin{array}{l}\text { ST strategy } \\
\text { ST }_{1} \text { Defining new tourist contents } \\
\text { and improving the quality in } \\
\text { accordance with the needs } \\
\text { of tourists and available } \\
\text { potentials }\end{array}$} & \multirow{2}{*}{\begin{tabular}{|c|} 
WT strategy \\
$\mathbf{W T}_{1}$ Development all-year-round \\
tourist contents availability
\end{tabular}} \\
\hline $\begin{array}{ll}\mathrm{T}_{1} & \begin{array}{l}\text { Adverse political and legal } \\
\text { situation; }\end{array} \\
\mathrm{T}_{2} & \begin{array}{l}\text { Negative impact of global warming } \\
\text { on precipitation and season length; }\end{array} \\
\mathrm{T}_{3} & \begin{array}{l}\text { A significant share of the gray } \\
\text { economy; }\end{array} \\
\mathrm{T}_{4} & \begin{array}{l}\text { High expectations of visitors in } \\
\text { terms of quality and variety of }\end{array} \\
& \text { content offered; } \\
\mathrm{T}_{5} & \text { Not enough interested investors; } \\
\mathrm{T}_{6} & \begin{array}{l}\text { Needs for continuous innovation of } \\
\text { the tourist offer. }\end{array}\end{array}$ & & \\
\hline
\end{tabular}


However, after defining potential strategies is necessary to make the strategies assessment (Step 3). For this purpose, the AHP methodology is applied. First of all, the importance of the SWOT groups in relation to the goal was determined (Table 6). The importance of each SWOT group is shown in Table 6, where it can be noticed that the highest importance is associated to the SWOT group Opportunities (0.461).

Table 6. Pairwise comparison of the SWOT groups

\begin{tabular}{|l|c|c|c|c|c|}
\cline { 2 - 6 } \multicolumn{1}{c|}{} & Strengths & Weaknesses & Opportunities & Threats & $\begin{array}{c}\text { Importance } \\
\text { of the SWOT } \\
\text { group }\end{array}$ \\
\hline Strengths & 1 & 2 & $1 / 3$ & 3 & 0.262 \\
\hline Weaknesses & & 1 & $1 / 2$ & 1 & 0.153 \\
\hline Opportunities & & & 1 & 3 & 0.461 \\
\hline Threats & & & & 1 & 0.124 \\
\hline
\end{tabular}

Inconsistency 0.07

Then, a comparison by SWOT factor pairs within each SWOT group was performed (Tables 7-10).

Table 7. Pairwise comparison of the SWOT factors - Strengths

\begin{tabular}{|l|c|c|c|c|c|c|}
\cline { 2 - 7 } \multicolumn{1}{c|}{} & $\mathbf{S}_{\mathbf{1}}$ & $\mathbf{S}_{\mathbf{2}}$ & $\mathbf{S}_{\mathbf{3}}$ & $\mathbf{S}_{4}$ & $\mathbf{S}_{\mathbf{5}}$ & $\mathbf{S}_{\mathbf{6}}$ \\
\hline $\mathbf{S}_{\mathbf{1}}$ & 1 & 2 & 1 & 4 & 2 & 3 \\
\hline $\mathbf{S}_{\mathbf{2}}$ & & 1 & 1 & 3 & 2 & 1 \\
\hline $\mathbf{S}_{\mathbf{3}}$ & & & 1 & 4 & 1 & 2 \\
\hline $\mathbf{S}_{\mathbf{4}}$ & & & & 1 & $1 / 3$ & 1 \\
\hline $\mathbf{S}_{\mathbf{5}}$ & & & & & 1 & 2 \\
\hline $\mathbf{S}_{\mathbf{6}}$ & & & & & & 1 \\
\hline
\end{tabular}

Inconsistency 0.03

Table 8. Pairwise comparison of the SWOT factors - Weaknesses

\begin{tabular}{|l|c|c|c|c|c|c|c|}
\cline { 2 - 8 } \multicolumn{1}{c|}{} & $\mathbf{W}_{\mathbf{1}}$ & $\mathbf{W}_{\mathbf{2}}$ & $\mathbf{W}_{\mathbf{3}}$ & $\mathbf{W}_{\mathbf{4}}$ & $\mathbf{W}_{\mathbf{5}}$ & $\mathbf{W}_{\mathbf{6}}$ & $\mathbf{W}_{\mathbf{7}}$ \\
\hline $\mathbf{W}_{\mathbf{1}}$ & 1 & $1 / 2$ & $1 / 3$ & $1 / 3$ & $1 / 2$ & $1 / 3$ & $1 / 2$ \\
\hline $\mathbf{W}_{\mathbf{2}}$ & & 1 & 1 & 3 & 3 & 4 & 3 \\
\hline $\mathbf{W}_{\mathbf{3}}$ & & & 1 & 2 & 3 & 1 & 3 \\
\hline $\mathbf{W}_{\mathbf{4}}$ & & & & 1 & 1 & 1 & 3 \\
\hline $\mathbf{W}_{\mathbf{5}}$ & & & & & 1 & 2 & 3 \\
\hline $\mathbf{W}_{\mathbf{6}}$ & & & & & & 1 & 3 \\
\hline $\mathbf{W}_{\mathbf{7}}$ & & & & & & & 1 \\
\hline
\end{tabular}

Inconsistency 0.07 
Table 9. Pairwise comparison of the SWOT factors - Opportunities

\begin{tabular}{|l|c|c|c|c|c|}
\cline { 2 - 6 } \multicolumn{1}{c|}{} & $\mathbf{O}_{1}$ & $\mathbf{O}_{2}$ & $\mathbf{O}_{3}$ & $\mathbf{O}_{4}$ & $\mathbf{O}_{5}$ \\
\hline $\mathbf{O 1}$ & 1 & 2 & 2 & 3 & 2 \\
\hline $\mathbf{O 2}$ & & 1 & 2 & 3 & 1 \\
\hline $\mathbf{0 3}$ & & & 1 & 3 & 1 \\
\hline $\mathbf{0 4}$ & & & & 1 & 1 \\
\hline $\mathbf{0 5}$ & & & & & 1 \\
\hline
\end{tabular}

Inconsistency 0.05

Table 10. Pairwise comparison of the SWOT factors - Threats

\begin{tabular}{|l|c|c|c|c|c|c|}
\cline { 2 - 7 } \multicolumn{1}{c|}{} & $\mathbf{T}_{\mathbf{1}}$ & $\mathbf{T}_{\mathbf{2}}$ & $\mathbf{T}_{\mathbf{3}}$ & $\mathbf{T}_{\mathbf{4}}$ & $\mathbf{T}_{\mathbf{5}}$ & $\mathbf{T}_{\mathbf{6}}$ \\
\hline T1 & 1 & 3 & 1 & $1 / 2$ & 3 & $1 / 2$ \\
\hline T2 & & 1 & $1 / 2$ & $1 / 3$ & 1 & $1 / 3$ \\
\hline T3 & & & 1 & $1 / 3$ & 1 & $1 / 3$ \\
\hline T4 & & & & 1 & 3 & 1 \\
\hline T5 & & & & & 1 & $1 / 3$ \\
\hline T6 & & & & & & 1 \\
\hline
\end{tabular}

Inconsistency 0.02

Finally, importance of SWOT groups and factors is presented in Table 11.

Table 11. The importance of the criteria and sub-criteria of the SWOT analysis

\begin{tabular}{|l|c|c|c|}
\hline SWOT group (importance) & SWOT factor & Importance (local) & Importance (global) \\
\hline \multirow{4}{*}{ Strengths (0.262) } & $\mathrm{S}_{1}$ & $\mathbf{0 . 2 8 0}$ & 0.07336 \\
\cline { 2 - 4 } & $\mathrm{S}_{2}$ & 0.185 & 0.04847 \\
\cline { 2 - 4 } & $\mathrm{S}_{3}$ & 0.208 & 0.054496 \\
\cline { 2 - 4 } & $\mathrm{S}_{4}$ & 0.065 & 0.01703 \\
\cline { 2 - 4 } & $\mathrm{S}_{5}$ & 0.161 & 0.042182 \\
\hline \multirow{4}{*}{ Weaknesses (0.153) } & $\mathrm{W}_{1}$ & 0.060 & 0.00918 \\
\cline { 2 - 4 } & $\mathrm{W}_{2}$ & $\mathbf{0 . 2 7 6}$ & 0.042228 \\
\cline { 2 - 4 } & $\mathrm{W}_{3}$ & 0.216 & 0.033048 \\
\cline { 2 - 4 } & $\mathrm{W}_{4}$ & 0.126 & 0.019278 \\
\cline { 2 - 4 } & $\mathrm{W}_{5}$ & 0.131 & 0.020043 \\
\cline { 2 - 4 } & $\mathrm{W}_{6}$ & 0.129 & 0.019737 \\
\cline { 2 - 4 } & $\mathrm{W}_{7}$ & 0.063 & 0.009639 \\
\hline \multirow{5}{*}{ Opportunities (0.461) } & $\mathrm{O}_{1}$ & $\mathbf{0 . 3 3 8}$ & 0.155818 \\
\cline { 2 - 4 } & $\mathrm{O}_{2}$ & 0.231 & 0.106491 \\
\cline { 2 - 4 } & $\mathrm{O}_{3}$ & 0.175 & 0.080675 \\
\cline { 2 - 4 } & $\mathrm{O}_{4}$ & 0.097 & 0.044717 \\
\cline { 2 - 4 } & $\mathrm{O}_{5}$ & 0.160 & 0.07376 \\
\cline { 2 - 4 } & & & \\
\hline
\end{tabular}




\begin{tabular}{|c|c|c|c|}
\hline \multirow{4}{*}{ Threats (0.124) } & $\mathrm{T}_{1}$ & 0.169 & 0.020956 \\
\cline { 2 - 4 } & $\mathrm{T}_{2}$ & 0.075 & 0.0093 \\
\cline { 2 - 4 } & $\mathrm{T}_{3}$ & 0.114 & 0.014136 \\
\cline { 2 - 4 } & $\mathrm{T}_{4}$ & $\mathbf{0 . 2 7 9}$ & 0.034596 \\
\cline { 2 - 4 } & $\mathrm{T}_{5}$ & 0.084 & 0.010416 \\
\cline { 2 - 4 } & $\mathrm{T}_{6}$ & $\mathbf{0 . 2 7 9}$ & 0.034596 \\
\hline
\end{tabular}

Table 12. Final rank of defined strategies

\begin{tabular}{|c|c|c|}
\hline Strategy & Importance & Rank \\
\hline $\mathbf{W T}_{\mathbf{1}}$ & 0.211 & 2 \\
\hline $\mathbf{S T}_{\mathbf{1}}$ & 0.196 & 3 \\
\hline $\mathbf{S O}_{\mathbf{1}}$ & 0.183 & 4 \\
\hline $\mathbf{W O}_{\mathbf{1}}$ & 0.152 & 5 \\
\hline $\mathbf{S O}_{\mathbf{2}}$ & 0.136 & 6 \\
\hline $\mathbf{W O}_{\mathbf{2}}$ & 0.122 & \\
\hline
\end{tabular}

Inconsistency 0.05

The results presented in Table 10. indicate the dominant influence of the following factors: $\mathrm{S}_{1}$ - Significant development potential and tradition in the tourism sector $(0.280) ; W_{2}$ - Constant decline in infrastructure quality levels (0.276); $O_{1}$ - Lack of strategy and goals (0.338). Within the SWOT group Threats to the factors $T_{4}$ - High expectations of visitors in terms of quality and variety of content offered and $T_{6}$ - is associated the same importance (0.279). It can be observed that the highest importance is given to $\mathrm{O}_{1}$, consequently with a great influence on the selection of strategy. Based on the above results, the final ranking of the considered strategies was obtained and it is presented in Table 12 .

Strategy $W T_{1}$ - development all-year-round tourist contents availability stands out as the top ranked strategy. On this basis it can be concluded that it is necessary to extend the duration of the tourist season from the current 3 months to 12 months. Second-ranked strategy $\mathrm{ST}_{1}$ may be a contributing factor to the implementation of the $\mathrm{WT}_{1}$ because it implies defining new tourist contents and improving the quality in accordance with the needs of tourists and available potentials.

In order to check the reliability of the results, a sensitivity analysis was also performed (Step 4). It aims to determine how changes in the importance of SWOT groups or factors affect changes in the ranking of strategies. All SWOT groups as well as the most significant factors were analyzed (Table 13).

According to the results of the sensitivity analysis, it can be noticed that the highest sensitivity was expressed by the SWOT group Threats $(+15)$ and the lowest by Strengths $(+44.5)$. In case of a change in the importance of the factors $\mathrm{S}_{1}, \mathrm{~W}_{2}, \mathrm{~T}_{4}$ and $\mathrm{T}_{6}$, even a change to the maximum or minimum value of the importance does not change the ranking of the strategies. Certain changes in strategy rankings are achieved by reducing the value of $\mathrm{O}_{1}$ to 0 (Table 12). All changes leading to a change in strategy rankings are $\geq 10 \%$ of the SWOT group and factor benchmark, so it can be concluded that the results obtained are relevant. 
Table 13. Sensitivity analysis

\begin{tabular}{|c|c|c|c|c|}
\hline \multirow{2}{*}{$\begin{array}{l}\text { SWOT } \\
\text { group }\end{array}$} & \multirow{2}{*}{ Initial priority } & \multicolumn{3}{|c|}{ Minimal change } \\
\hline & & + or - & Strategy & Priority \\
\hline \multirow{6}{*}{ Strengths } & \multirow{6}{*}{26.2} & \multirow{6}{*}{+44.5} & $\mathrm{SO}_{1}$ & 21.6 \\
\hline & & & $\mathrm{SO}_{2}$ & 10.5 \\
\hline & & & $\mathrm{ST}_{1}$ & 23.8 \\
\hline & & & $\mathrm{WO}_{1}$ & 10.8 \\
\hline & & & $\mathrm{WO}_{2}$ & 9.7 \\
\hline & & & $\mathrm{WT}_{1}$ & 23.7 \\
\hline \multirow{6}{*}{ Weaknesses } & \multirow{6}{*}{15.3} & \multirow{6}{*}{+24.5} & $\mathrm{SO}_{1}$ & 16.3 \\
\hline & & & $\mathrm{SO}_{2}$ & 13.5 \\
\hline & & & $\mathrm{ST}_{1}$ & 17.5 \\
\hline & & & $\mathrm{WO}_{1}$ & 18.5 \\
\hline & & & $\mathrm{WO}_{2}$ & 16 \\
\hline & & & $\mathrm{WT}_{1}$ & 18.3 \\
\hline \multirow{6}{*}{ Opportunities } & \multirow{6}{*}{46.1} & \multirow{6}{*}{-27.8} & $\mathrm{SO}_{1}$ & 17.7 \\
\hline & & & $\mathrm{SO}_{2}$ & 11.4 \\
\hline & & & $\mathrm{ST}_{1}$ & 19.2 \\
\hline & & & $\mathrm{WO}_{1}$ & 17.6 \\
\hline & & & $\mathrm{WO}_{2}$ & 15 \\
\hline & & & $\mathrm{WT}_{1}$ & 19.1 \\
\hline \multirow{6}{*}{ Threats } & \multirow{6}{*}{12.4} & \multirow{6}{*}{+15} & $\mathrm{SO}_{1}$ & 16.7 \\
\hline & & & $\mathrm{SO}_{2}$ & 13.2 \\
\hline & & & $\mathrm{ST}_{1}$ & 17.6 \\
\hline & & & $\mathrm{WO}_{1}$ & 19.1 \\
\hline & & & $\mathrm{WO}_{2}$ & 14.4 \\
\hline & & & $\mathrm{WT}_{1}$ & 19 \\
\hline \multicolumn{2}{|l|}{$\mathbf{S}_{1}$} & \multirow{2}{*}{\multicolumn{3}{|c|}{$\begin{array}{l}\text { There is no change in the ranking of the top ranked strategy even with max } \\
\text { decrease or increase. }\end{array}$}} \\
\hline \multicolumn{2}{|l|}{$\mathbf{W}_{2}$} & & & \\
\hline \multirow{6}{*}{$O_{1}$} & \multirow{6}{*}{33.8} & \multirow{6}{*}{-33.8} & $\mathrm{SO}_{1}$ & 18.5 \\
\hline & & & $\mathrm{SO}_{2}$ & 15.6 \\
\hline & & & $\mathrm{ST}_{1}$ & 18.7 \\
\hline & & & $\mathrm{WO}_{1}$ & 16.2 \\
\hline & & & $\mathrm{WO}_{2}$ & 12.4 \\
\hline & & & $\mathrm{WT}_{1}$ & 18.6 \\
\hline \multicolumn{2}{|l|}{$\frac{\mathbf{T}_{4}}{\mathbf{T}_{6}}$} & \multicolumn{3}{|c|}{$\begin{array}{l}\text { There is no change in the ranking of the top ranked strategy even with max } \\
\text { decrease or increase. }\end{array}$} \\
\hline
\end{tabular}




\section{CONCLUSION}

In this paper, the SWOT-AHP methodology was applied to determine the current state of the Brezovica ski resort. Also, based on the determined situation, 6 appropriate strategies for tourism development were defined. $\mathrm{WT}_{1}$ (development all-year-round tourist contents availability) stands out as the top strategy. The above strategy envisages extending the tourist offer to the whole year. In this way, a significantly higher number of tourists can be expected, which will contribute to increased revenues but also to better utilization of existing resources and infrastructure.

In order to verify the results obtained, a sensitivity analysis of SWOT groups and factors was conducted. Only with a significant change of importance $(\geq 10 \%)$ of SWOT groups and factors, changes occur in the ranking of strategies, which leads to the conclusion that the results obtained are reliable. Also, the proposed model is characterized by universality which allow it can be applied in other areas.

In the future studies it is necessary to determine the appropriate additional tourist contents that will complement the offer of the Brezovica ski resort and be available throughout the year. In this regard, the attitudes of existing and potential visitors/tourists should also be included. Also, the model proposed in this paper can be improved by including relevant stakeholders in the process of analyzing and defining strategies.

\section{REFERENCES}

Agrawala, S. (2007). Climate change in the European Alps. Adapting winter tourism and natural hazards management. Paris: OECD.

Alptekin, N., (2013). Integration of SWOT analysis and TOPSIS method in Strategic Decision-Making Process. Macrotheme review, 2(7), 1-8.

Ballotta, L., Fusai, G., Kyriakou, I., Papapostolou, N., Pouuliasis, P. (2020). Risk management of climate impact for tourism operators: An empirical analysis on ski resorts. Tourism Management, 77, 104011.

Buta, R., (2007). The SWOT analysis in the geographical research, with applicability in the study of the human settlements from Moldova valley. Present Environment and Sustainable Development, 1, 239-248.

Damnjanović, I., (2014). Geografski informacioni sistemi u funkciji unapređenja promocije turističkih proizvoda nacionalnih parkova Srbije, Univerzitet Singidunum, Departman za poslediplomske studije i međunarodnu saradnju, Beograd.

Eslamipoor, R., Sepehriar, A. (2014). Firm relocation as a potential solution for environment improvement using a SWOT-AHP hybrid method. Process safety and environmental protection, 92 (3), 269-276.

European Union tourism trends, 2018, World tourism organization.

Fabac, R., Zver, I., (2011). Applying the modified SWOT-AHP method to the tourism of Gornje Međimurje. Tourism and Hospitality Management, 17 (2), 201-215.

Houben, G., Lenie, K., Vanhoof, K. (1999). A knowledge-based SWOT-analysis system as an instrument for strategic planning in small and medium sized enterprises. Decision support systems, 26 (2), 125-135.

Kajanus, M., Kangas, J., Kurttila, M. (2004). The use of value focused thinking and the A'WOT hybrid method in tourism management. Tourism management, 25 (4), 499-506. 
Kangas, J. et al. (2003). Evaluating the management strategies of a forestland estate the SO-S approach. Journal of Environmental Management, 69, 349-358.

Kurttila, M., Pesonen, U.M., Kangas, J., Kajanus, M. (2000). Utilizing the analytic hierarchy process AHP in SWOT analysis - a hybrid method and its application to a forest certification case. Forest policy and economics, 1 (1), 41-52.

Lee, S., Walsh, P. (2011). SWOT and AHP hybrid model for sport marketing outsourcing using a case of intercollegiate sport. Sport management review, 14 (4), 361-369.

Mansury, Y., Hara, T. (2007) Impacts of Organic Food Agritourism on a Small Rural Economy: A Social Accounting Matrix Approach, The Journal of Regional Analysis \& Policy, 37(3), 213-222.

Masozera, M.K., Alavalapati, J.R.R., Jacobson, S.K., Shrestha, R.K. (2006). Assessing the suitability of community-based management for the Nyungwe Forest Reserve, Rwanda, Forest policy and economics, 8 (2), 206-216.

Mehmood, F., Hassannezhad, M., Abbas, T. (2014). Analytical investigation of mobile NFC adaption with SWOT-AHP approach: A case of Italian Telecom. Procedia technology,12, $535-541$.

Nikolić, Đ., Spasić, J., Živković, Ž., Đorđević, P, Mihajlović, I., Kangas, B., (2015). Swot - ahp model for prioritization of strategies of the resort Stara planina. Serbian Journal of Management, 10 (2), $141-150$.

Ren, J., Sovacool, B. (2015). Prioritizing low-carbon energy sources to enhance China's energy security. Energy conversion and management, 92, 129-136.

Saaty T.L. (1980). The Analytic Hierarchy Process: Planning, Priority Setting, Resource Allocation. New York, USA: McGraw-Hill.

Saaty, T. L. (1993). The Analytic Hierarchy Process: a 1993 overview. Central European journal of operation research and economics, 2 (2), 119-137.

Shahabi, R.S., Basiri M.H., Kahag M.R., Zonouzi S.A. (2014). An ANP SWOT approach for interdependency analysis and prioritizing the Iran's steels crap industry strategies. Resources policy, 42, 18-26.

Sharma, M. J., Moon, I., Bae, H. (2008). Analytic hierarchy process to assess and optimize distribution network. Applied mathematics and computation, 202 (1), 256-265.

Shinno, H., Yoshioka, H., Marpaung, S., and Hachiga, S. (2006). Quantitative SWOT analysis on global competitiveness of machine tool industry. Journal of engineering design, 17 (3), 251-258.

Simpson, M. C., Gössling, S., Scott, D., Hall, C. M., \& Gladin, E. (2008). Climate change adaptation and mitigation in the tourism sector: Frameworks, tools and practices. Paris: UNEP, University of Oxford, UNWTO, WMO.

Srivastava, P.K., Kulshreshtha, K., Monhanty, C.S., Pushpangadan, P., Singh, A., (2005). Stakeholder-based SWOT analysis for successful municipal solid waste management in Lucknow, India. Waste Management, 25 (5), 531-537.

Stojčetović, B., Nikolić Đ., Živković, Ž., Bogdanović D. (2018). Swot-ahp method application to determine current energy situation and define strategies for energy security improvement. Thermal science, 23 (2b), 861-872.

Stojčetović, B., Nikolić, Đ., Velinov, V., Bogdanović, D. (2016). Application of integrated strengths, weaknesses, opportunities, and threats and analytic hierarchy process methodology to renewable energy project selection in Serbia, Journal of renewable and sustainable energy, 8, 035906.

Terry, H., Westbrook, R. (1997). SWOT analysis: it's time for a product recall. Long Range Planning, 30(1), 46-52. 
Yuksek, I., Akin, A. (2006). Determination strategy in business with analytic hierarchy process. Dogus university journal, 7, 2, 254-268.

Zhenhua L. M. (2003) Sustainable tourism development: A critique, Journal of Sustainable Tourism, 11(6), 465-467. 